\title{
Eksistensi Perempuan Mesir dalam Novel Perempuan di Titik Nol Karya Nawal El-Saadawai
}

\author{
Firman Syah1*, Fadlil Yani Ainusyamsi², Asep Supianudin³ \\ 1*2,3UIN Sunan Gunung Djati Bandung; 1689firman@gmail.com,2fy.ainusyamsi@gmail.com, \\ 3asepsupianudin@uinsgd.ac.id
}

*Penulis Korespondensi

Artikel Dikirim: 12 Mei 2021;

Artikel Diterima: 19 Mei 2021;

Artikel Dipubikasikan: 21 Juni 2021

\begin{abstract}
Abstrak: Perempuan dan eksistensi adalah dua kata yang sulit untuk disatukan, eksistensi perempuan merupakan sesuatu yang mengharukan apabila dapat terwujud. Perempuan banyak terjerembap dalam jurang perbudakan baik itu fisik, mental dan emosional. Dari alas an tersebut, dapat dikatakan bahwa konsekuensi logis yang diterima perempuan yaitu dapat terdegradasi dari kesempatan dan peluang dalam hal aktualisasi potensi diri. Tujuan dari penelitian ini adalah untuk mengetahui bentuk ketidakadilan gender seperti marjinalisasi, subordinasi, streotip, kekerasan dan beban kerja tambahan. Selain itu, peneliti ingin mengetahui bentuk eksistensi perempuan, karena itu adalah salah satu bentuk perlawanan yang dilancarkan perempuan di ranah publik. Metode yang digunakan dalam penelitian ini yaitu metode deskriptif-analitik dengan menggunakan pendekatan feminism eksistensialis. Adapun sumber data pada penelitian ini diambil dari novel. Novel tersebut berjudul Perempuan di Titik Nol karya Nawal El-Saadawi. Hasil penelitian ini mendeskripsikan bentuk ketidakadilan gender dan bentuk eksistensi perempuan dalam novel Novel Perempuan di Titik Nol karya Nawal El-Saadawi.
\end{abstract}

Kata Kunci: Feminisme, Feminisme Eksistensialis, Gender

\begin{abstract}
The words of woman and existence are difficult to put together, the existence of women makes it better if it can be realized. Many women fall into the abyss of slavery both physically, mentally, and emotionally. For that reason, it can be said that the logical consequence is that women can be relegated from the chance and opportunities in terms of potential for self-actualization. The purpose of this study was to determine the forms of gender inequality such as marginalization, subordination, stereotypes, violence, and additional workload. In addition, the researcher wants to know the form of women's existence, because it is a form of resistance launched by women in the public sphere. Descriptiveanalytic methods are used in this research with the existentialist feminism approach. Furthermore, the data are collected from novels. The novels title are Perempuan di Titik Nol are written by Nawal ElSaadawi. The result of this research describes the form of gender inequality and the form of women's existence which is illustrated from the novel Perempuan di Titik Nol by Nawal El-Saadawi.
\end{abstract}

Keywords: Feminism, Existentialist Feminism, Gender

\section{Pendahuluan}

Menjalani eksistensi diri merupakan tugas setiap individu. Dalam eksistensi diri tersebut, manusia menemukan dirinya dalam kebebasan. Untuk mencapai hal tersebut, manusia membutuhkan pembebasan terhadap segala ketidakadilan yang membatasi ruang geraknya. Jika dikaitkan dengan perempuan, eksistensi dapat dimaknai sebagai cara perempuan memahami keberadaan dirinya sebagai manusia yang diperhadapkan dengan sejumlah pilihan (Batu, 2007). Pemaknaan tersebut menjadikan eksistensi sebagai alat, bagi perempuan untuk memaknai dirinya lebih mendalam dan dari pemaknaan tersebut perempuan akan lebih siap ketika diperhadapkan oleh berbagai realitas. 
Eksistensi menurut Sartre mendahului esensi. Keberadaan eksistensi yang mendahului esensi akan menjadikan manusia bertanggung jawab atas hidupnya. Dengan demikian, eksistensialisme menempatkan manusia pada posisinya sebagai dirinya sendiri, dan meletakkan keseluruhan tanggung jawab hidupnya sepenuhnya di atas pundak manusia itu sendiri. Manusia yang bertanggung jawab atas hidupnya sendiri tidak berarti bahwa tanggung jawabnya hanya meliputi individualitasnya sendiri, tetapi mencakup tanggung jawab atas semua manusia (Sartre \& Jean-Paul, 2002).

Sejak lahir, konstruksi sosial dan budaya sudah membentuk perempuan sedemikian rupa untuk memenuhi kodrat sebagai istri dan ibu yang harus setia pada ranah domestik. Mainan boneka dan masak-masakan sebagai atribut "keperempuanan" kerap menjadi andalan orang tua sebagai media pembelajaran anak-anak perempuan yang kelak harus menjadi "wanita sejati” yang pintar berdandan, memasak, dan mengurus anak. Ketidakmampuan untuk memenuhi definisi itu menjadi bentuk pengingkaran terhadap kodrat dan kelalaian terhadap tanggung jawab. Akhirnya, perempuan dipaksa untuk memilih antara menggapai karir atau melaksanakan tanggung jawab di dalam rumah. Kenyataan ini sungguh menyedihkan karena sejatinya laki-laki pun memiliki tanggung jawab yang sama besarnya untuk mengurus rumah tangga. Semua tugas harus dibagi secara adil, baik di ranah publik maupun domestik.

Sejarah mencatat sudah sejak lama laki-laki menggunakan motif-motif norma dan moral sebagai legitimasi posisinya menjadi individu yang superior atas perempuan yang dianggap sebatas subordinat. Laki-laki, dengan begitu, mendesak perempuan untuk terus menjadi eksistensi yang termarginalkan, terpinggirkan, dan hanya sekadar pelengkap. Laki-laki yang menjadi penguasa dan pembentuk budaya membuat perempuan merasa bahwa apa yang selama ini mereka alami tidak lain kecuali bagian dari takdir dan kodrat yang harus mereka pikul tanpa perlu mengajukan pertanyaanpertanyaan bernada skeptis. Dengan memelihara kecurigaan terhadap dinamika sosial yang telah dianggap baku, masyarakat akan menyangka ada yang salah dalam diri pribadi perempuan, atau dalam bahasa populer bisa jadi ia dianggap melakukan tindakan yang tidak-feminin.

Muara dari bentukan budaya itu memberi kebebasan mutlak kepada laki-laki untuk mengendalikan perempuan. Mereka berusaha mengubahnya sesuai dengan keinginanya. konstruksi sosial yang melanggengkan dinasti kekuasaan laki-laki, perempuan menyerahkan dirinya secara pasif kepada kemauan laki-laki dan membiarkan terjadinya asimilasi. Dengan demikian, laki-laki menjadi pemilik perempuan dan memanfaatkannya (Simone de Beauvoir, 2003). Kompleksitas budaya dan kontruksi sosial yang sejak dahulu hingga sekarang mendera perempuan membuat perempuan tidak dapat berbuat banyak. Pada lain sisi kontruksi sosial dan budaya memudahkan laki-laki untuk memanfaatkan perempuan sesuai dengan kemauanya.

Perjuangan perempuan untuk menuntut hak-hak mereka sebagai manusia seutuhnya merupakan perlawanan terhadap pembagian kerja yang menetapkan kaum laki-laki sebagai pihak yang berkuasa dalam ranah publik. Maka dari itu, munculah feminisme sebagai gerakan sosial yang pada mulanya berangkat dari asumsi bahwa pada dasarnya kaum perempuan ditindas dan dieksploitasi, di mana melaluinya pula (feminisme) perempuan berusaha untuk mengakhiri penindasan dan eksploitasi tersebut (Fakih, 1996). Secara konsisten feminisme dari masa ke masa mampu mengakomidir keresahan-keresahan yang terjadi pada diri perempuan. Seberkas sinar tentang masa depan perempuan 
yang lebih cerah dan jauh dari berbagai usaha yang ingin memarginalkan perempuan, mulai tampak sedikit demi sedikit namun pasti.

Novel Perempuan di Titik Nol merupakan karya sastra yang ditulis berdasarkan hasil penelitian seorang penulis bernama Nawal el Sa'adawi. Ia telah melakukan banyak riset bertemakan pembebasan kaum perempuan dari perlakuan sewenang-wenang budaya patriarkis. Perempuan di (hampir) setiap kebudayaan ditempatkan pada posisi di bawah dominasi laki-laki. Mereka seringkali dianggap dan dijadikan sebagai manusia kelas dua di bawah laki-laki yang selalu digolongkan sebagai manusia kelas satu, Sa'adawi berusaha membongkar perilaku patriarki tersebut struktur serta bermaksud menegaskan bahwa perempuan dan laki-laki mempunyai martabat kemanusiaan yang sama. Karena alasan itu saya mengangkat pemikiran Nawal el Sa'adawi mengenai perempuan yang ditampilkan dalam novel Perempuan di Titik Nol (Pranowo, 2016).

Metode yang digunakan dalam penelitian ini adalah metode deskriptif analitik dengan meggunakan pendekatan feminisme eksistensialis. Metode deskriptif analitik mencari pemecahan masalah dengan cara memahami gambaran yang ada pada novel dan menganalisanya. Pendekatan feminisme eksistensialis yang disusun oleh Beauvoir dengan empat strateginya yaitu bekerja, mendalami kemampuan intelektual, menjadi agen transformasi sosial di masyarakat dan menolak keliyananya, membantu perempuan untuk menunjukan eksistensinya (Sholihah, 2018). Eksistensi menjadikan perempuan sebagai titik pusatnya dan eksistensi perempuan sebagai bentuk aktualisasi yang akan dilakukan oleh perempuan.

\section{Pembahasan}

\subsection{Feminisme}

Relasi feminisme dengan gender pada dasarnya sangat erat, relasi ini di aplikasikan selayaknya fenomena budaya yang memiliki peran perempuan (Beta, 2018). Mansour Fakih, menyatakan feminisme adalah gerakan yang mana berangkat dari kesadaran dan asumsi bahwa kaum perempuan dieksploitasi dan juga ditindas, yang tujuan dari gerakan ini adalah untuk mengakhiri eksploitasi dan penindasan tersebut. Esensi dari perjuangan feminis adalah martabat yang lebih baik, kesamaan serta kebebasan dalam menjalani kehidupan baik di dalam ataupun luar rumah (Mansour Fakih, 2008). Feminisme sebagai sebuah gerakan sosial sudah jamak praktiknya, langkah pertama dari sebuah gerakan feminisme adalah penyadaran akan peran dan fungsi perempuan baik itu dalam ruang-ruang publik dan domestik.

Aida Fatalaya, Feminisme mempunyai arti dari kata femina yang artinya memiliki sifat keperempuanan, jadi feminisme itu lahir, berangkat dari persepi tentang timpangnya posisi perempuan dibandingkan laki-laki di khalayak ramai. Sehingga respon yang diambil untuk mematahkan persepsi ini adalah, pengkajian terkait penyebab ketimpangan guna menemukan rumus penyetaran laki-laki dan perempuan dalam segala aspek, sesuai kapabilitas mereka sebagai manusia (Haningsih, 2005). Kedangkalan khalayak ramai dalam memaknai feminisme sering menuai mispersepsi yang pada akhirnya berujung pada ketimpangan sosial. Maka penyadaran terhadap masyarakat sangat penting adanya, guna menekan ketimpangan sosial ini. Feminisme menurut Goefe ialah teori tentang persamaan antara laki-laki dan perempuan di bidang politik, ekonomi,dan sosial atau kegiatan terorganisasi yang 
memperjuangkan hak-hak serta kepentingan perempuan (Sugihastuti \& Saptiawan, 2010). Feminisme sebagai gerakan perempuan muncul dalam karakteristik yang berbeda-beda yang disebabkan perbedaan asumsi dasar yang memandang persoalan persoalan yang menyebabkan ketimpangan gender. Komplekitas masalah yang di alami perempuan memunculkan corak feminisme yang beragam sesuai dengan takaran yang diperlukan, namun tetap muara dari setiap gerakan dan corak feminisme adalah memperjuangkan hak perempuan.

Feminisme menurut Goefe ialah teori tentang persamaan antara laki-laki dan perempuan di bidang politik, ekonomi,dan sosial atau kegiatan terorganisasi yang memperjuangkan hak-hak serta kepentingan perempuan (Sugihastuti \& Saptiawan, 2010). Feminisme sebagai gerakan perempuan muncul dalam karakteristik yang berbeda-beda yang disebabkan perbedaan asumsi dasar yang memandang persoalan persoalan yang menyebabkan ketimpangan gender. Komplekitas masalah yang di alami perempuan memunculkan corak feminisme yang beragam sesuai dengan takaran yang diperlukan, namun tetap muara dari setiap gerakan dan corak feminisme adalah memperjuangkan hak perempuan.

Sementara Mill dan Taylor mengejawantahkan feminisme sebagai gerakan perjuangan kaum perempuan demi tercapainya sebuah keadilan gender atau kesetaraan seksual. Caranya adalah pemberian perempuan hak dan peluang dalam berpolitik serta kesempatan dalam mengenyam pendidikan yang sama dengan laki-laki (Rosemarie Putnam Tong, 2004). Pemberian perempuan kesempatan untuk mengisi ruang-ruang publik sangatlah krusial, dengan diberinya kesempatan tersebut secara tidak langsung perempuan akan meningkatkan kualitas dirinya, untuk menunjang pekerjaan yan di dapat. Persoalanya adalah ketika perempuan tidak dapat diberi kesempatan tersebut, maka secara tidak langsung tertutuplah kesempatan untuk membuktikan kemampuan dirinya.

Feminisme jika di artikan secara umum adalah suatu paham yang membahas tentang perempuan, lantaran adanya keyakinan bahwa perempuan menanggung ketidakadilan karena jenis kelaminya (Beta, 2018)

Patut dipahami apabila feminisme bukanlah sebuah konsepsi homogen yang dapat mewakili perempuan dengan gerakan universal. Feminisme adalah konsepsi yang heterogen dan sangat lapang. Sebagai sebuah terma feminisme memayungi bermacam-macam pandangan, pendekatan dan kerangka berpikir sebagai penjelasan atas penindasan perempuan, berikut solusi untuk memecahkan masalah tersebut. (Suwastini, 2013). Luasnya pengejahwantahan feminisme di berbagai macam sisi, diharapkan bisa mengakomodir, berbagai permasalahan yang ada. Sebagai gerakan yang selalu mengupayakan perubahan terhadap perempuan, stagnansi dan tidak berkembangnya feminisme adalah hal yang harus selalu di hindari.

\subsection{Feminisme Eksistensialisme Simone de Beaouvoir}

Prancis yang telah disesaki oleh ide-ide filosofi yang ditanam oleh para laki-laki waktu, membuat feminisme muncul. Simone De Beauvoir termasuk orang yang paling awal dalam mengembangkan femnisme di Perancis. Lewat bukunya yang fenomenal The Second Sex, De Beauvoir mulai mengenalkan gagasanya tentang feminisme. Gagasan De Beauvoir mengenai feminisme eksistensialis tidak dapat 
dijauhkan dari kekasihnya Satre, karena yang menjadi dasar pondasi teori feminisme eksistensialis adalah teori eksistensialis milik Satre (Syahrul, 2017).

Beauvoir fenomenal dengan ungkapan pada bukunya Second Sex yaitu "on ne nait pas femme, on le devient". E.M. Parshey mengartikan ungkapan tersebut seperti berikut "seseorang tidak dilahirkan sebagai wanita tetapi menjadi seorang wanita" (Luise von Flotow, 2011).

Motif De Beauvoir untuk mengangkat emansipasai wanita lewat teori feminisme eksistensialis didasari oleh hal-hal berikut.

1. Perspektif biologis yang kaitanya dengan proses reproduksi yang dimiliki wanita sebagai bentuk kelemahan dan perendahan diri. Fakta yang terbangun tadi, menampakkan bahwa perempuan sukar untuk menjadi dirinya secara utuh terlebih ketika ia sudah mempunyai anak. De Beauvoir menolak perspektif tadi yang membuat kedudukan laki-laki dianggap sebagai superior ketimbang perempuan. Definisi perempuan tidak cukup hanya dilihat dari bentuk tubuhnya dan Biologi sendiri tidak mempunyai cukup penjelasan mengapa perempuan di jadikan objek atas yang lain (Beauvoir, 2003).

Dalam biologis, laki-laki dan perempuan memiliki peran reproduksi yang berbeda Dalam perkembangannya, laki-laki memiliki perkembangan yang sederhana sedangkan perempuan jauh lebih rumit. Perempuan juga memiliki struktur organ yang lebih lemah dibanding lakilaki, tulangnya lebih rapuh, kekuatan ototnya jauh lebih sedikit. Menstruasi bulanan, menopause, kehamilan, melahirkan merupakan karakteristik perempuan. Tubuh bukan semata-mata sebuah benda, tetapi situasi. Tubuh perempuan adalah salah satu unsur esensial dalam situasinya di dunia, tetapi tubuh itu sendiri belum mencukupi untuk mendefenisikannya sebagai perempuan; tak ada realitas yang sungguh-sungguh hidup kecuali yang termanifestasikan oleh kesadaran individual melalui aktifitas serta berada pada jantung masyarakat (Beauvoir, 2003).

2. Psikoanalisis Freudian berpendapat bahwa perempuan adalah mahluk yang sedang bergelut menghadapi kefeminiman dan kejantanan. Masalah ini dapat diatasi dengan jalan kepuasan klitoris untuk kejantanan dan kefeminiman dengan vagina. Menurut Beauvoir, Freud terlalu menggampangkan bahwa jawaban atas subordinasi yang dialami perempuan terdapat pada penjelasan seksual. Kebudayaan yang terbangun tidak hanya dapat dijelaskan dengan impuls seksual, karena hubungan antara laki-laki dan perempuan begitu juga kebudayaan lebih kompleks dari itu (Beauvoir, 2003).

Beauvoir menyatakan bahwa para penganut psikoanalisis kurang sempurna dalam menyatakan pendapatnya yang menempatkan posisi perempuan sebagai sang liyan. Adanya satu anggapan dari pera pemikir freudian bahwa laki-laki lebih tinggi derajatnya dibandingkan perempuan karena memiliki phallus (penis), karena itu adalah lambang kekuasaan. Perempuan didefinisikan sebagai betina, kontras dengan laki-laki yang dinamai sebagai manusia, kapanpun perempuan berperilaku sebagai manusia maka ia dikatakan meniru lakilaki (Beauvoir, 2003).

3. De Beauvoir juga menganggap penjelasan Marxis mengapa perempuan menjadi the other tidaklah memuaskan. Friedrich Engels (1820-1895) berargumentasi bahwa sejak awal 
perempuan melakukan pekerjaan dalam kategori "ada dalam dirinya" seperti memasak, mengurus rumah, mengurus anak. Sedangkan laki-laki melakukan pekerjaan dalam kategori "ada untuk dirinya" seperti berburu dan berkelahi. Pembagian kerja yang spesifik mengakibatkan nantinya laki-laki lebih menguasai alat produksi dan menjadi borjuis sedangkan perempuan menjadi proletar. Sehingga untuk mengubah keadaan tersebut menurut Engels haruslah sistem kapitalisme diubah sehingga adanya kewajiban merata antara laki-laki dan perempuan. Namun de Beauvoir tidak setuju dengan hal tersebut, karena perubahan dari sistem kapitalisme ke sosialisme tidak akan mengubah perempuan menjadi bukan the other, karena akar penindasan perempuan bukanlah sekedar faktor ekonomi, tetapi yang lebih utama adalah faktor ontologis (Rosemarie Putnam Tong, 2004).

Konsepsi ekonomi Marxis, menyatakan bahwa akar penindasan perempuan yang muncul diakibatkan oleh kelas-kelas yang ada dan tumbuh dimasyarakat. Penindasan yang ada disebabkan oleh kelas pemilik modal yang melakukan eksploitasi terhadap kelas buruh atau pekerja. Penindasan dapat dipadamkan dengan meruntuhkan kapitalisme. Selama kapitalisme masih berdiri kokoh, selama itu pula penindasan akan kelas, keturunan, bangsa dan jenis kelamin tidak dapat lenyap (Pranowo, 2016).

Beauvoir sebagai mitra intelektual Satre, mengambil bahasa etis eksistensialisme dan ontologis Satre. Beauvoir memberikan penamaan untuk laki-laki sebagai sang Diri dan penamaan untuk perempuan sebagai sang Liyan. Apabila kehadiran Liyan merupakan ancaman bagi Diri. Maka kehadiran perempuan adalah sebuah ancaman bagi laki-laki (Beauvoir, 2003; Rosemarie Putnam Tong, 2004).

Batasan feminitas yang membelenggu tidak hanya dialami oleh istri dan ibu, perempuan pekerja juga mengalami hal serupa. Bahkan dalam beberapa sisi keadaannya lebih buruk dari istri dan ibu yang berada dirumah dan tidak bekerja di sektor yang erat dengan khalayak ramai. Perempuan pekerja dengan sekelumit tugas yang diterimanya, mesti secara kontinu untuk menjadi perempuan dalam sikap, berperilaku dan berbuat sebagai perempuan seutuhnya. Artinya pekerjaanya harus melibatkan sisi feminitasnya, hal ini diterjemahkan oleh masyarakat sebagai keharusan dalam berpenampilan menarik (Rosemarie Putnam Tong, 2004).

Pertarungan antara keharusan menjadi profesional dan hajat feminitasnya akan menciptakan konflik internal dalam diri perempuan. Apabila perempuan memilih profesional dalam bekerja maka dia tidak akan mengindahkan pribadinya dalam berpenampilan. Kenyataan yang dihadapi selanjutnya perempuan tidak dapat memenuhi standar kecantikan yang dibangun oleh para perempuan. Sikap skeptis muncul khawatir penampilanya tidak sesuai standar, untuk memenuhi itu maka perempuan melakukan pemotongan waktu kerja untuk mengurus kecantikanya. Keadaan yang pelik ini membuat karakteristik yang dikehendaki perempuan yaitu narsisme tidak dapat didirikan (Rosemarie Putnam Tong, 2004).

Kebebasan yang diinginkan oleh laki-laki dapat tercapai apabila subordinasi dilakukan terhadap perempuan. Fakta historis yang saling bertautan adalah opresi terhadap perempuan dan yang kedua adalah perempuan telah menghayati pandangan asing yang menganggap bahwa perempuan tidak esensial tidak seperti laki-laki yang esensial (Beauvoir, 2003; Simone de Beauvoir, 2003). 
Berangkat dari kegelisahan dan ketidak puasanya terhadap konsespi Biologi, Psikoanalisis Freud dan Marxis yang tidak memberikan Beauvoir jawaban yang memuaskan mengapa perempuan masih di kesampingkan daripada laki-laki. Menurutnya ada penjelasan yang paling asasi dan mendasar mengenai penempatan perempuan pada sebuah ruangan yang bernama Liyan. Beauvoir berpandangan bahwa ketika laki-laki menunjukkan dirinya adalah subjek dan ada yang bebas maka ketika itu pandangan bahwa perempuan adalah Liyan pun muncul. (Beauvoir) Dominasi akan dikendalikan oleh laki-laki karena jika tidak maka perempuan akan menjadi sang Diri sebaliknya laki-laki akan menjadi sang Liyan (Rosemarie Putnam Tong, 2004).

Kebudayaan yang kian berkembang, berbarengan dengan itu laki-laki membuat mitos guna menguasai perempuan. Perempuan di proyeksikan sebagai mahluk yang sulit dimengerti, rumit dan irasional (Simone de Beauvoir, 2003).

Beauvoir melalui Tong lewat telaahnya tentang mitos yang dibuat laki-laki tentang perempuan, menegaskan bahwa setiap laki-laki selalu dalam proses pencarian terhadap perempuan yang ideal. Perempuan yang ideal adalah perempuan yang akan menggenapkan kekuranganya (Rosemarie Putnam Tong, 2004).

Manusia entah itu laki-laki ataupun perempuan tidak mempunyai esensi, maka tidak ada kewajiban bagi perempuan untuk menjelma apa-apa yang laki-laki harapkan. Kegiatan postif, penghapusan peran yang telah erat menempel padanya ataupun redefinisi ulang dirinya karena sejatinya dalam proses pembangunan pribadinya tiada esensi praktis pada feminitas yang siap pakai, melainkan hasil kontruksi perempuan sendiri (Beauvoir, 2003).

Pada akhirnya kerikil tajam yang merintangi jalan perempuan akan berakhir juga. Telah tiba saatnya bagi perempuan untuk insyaf dan sadar bahwa perempuan adalah subjek layaknya laki-laki. Maka ada dalam dirinya sendiri juga dapat dilakukan oleh perempuan (Rosemarie Putnam Tong, 2004).

Transendensi menurut Beauvoir adalah jawaban bagi perempuan dalam menghadapi permasalahan perempuan yang makin kompleks. Secara definitif transendensi memiliki arti "melampaui". Transendensi diejawantahkan sebagai proses gerak manusia meninggalkan alam fakta menembusi dinding pembatas konkret, yang bermuara pada iklim di luar hakikat manusia dan diawalai oleh serangkaian dinamika mental dan rohaniah (Heraty, 2018).

Landasan penggunaan istilah transendensi adalah filsafat eksistensialis milik Satre. Sehingga apabila di telisik lebih dalam kalimat transendensi feminin di maknai "aktualisasi dalam diri perempuan sebagai pribadi yang bebas dan merdeka". Kebebasan perempuan akan mewujud dalam transendensi. Sebagai sebuah penggambaran gerakan yang dinamis, setiap saat manusia akan menyatakan dirinya lantas pergi meninggalkan dirinya dan saat ini menyiapkan dirinya untuk masa yang akan datang (Heraty, 2018).

Untuk mencapai transendensi, Beauvoir menggunakan empat strategi (Beauvoir, 2003; Simone de Beauvoir, 2003).

1. Bekerja

Seberapapun kerasnya dan lelahnya perempuan dalam menanggung beban pekerjaan yang akan ditanggungnya, Beauvoir bersikukuh bahwa dengan bekerja setidaknya perempuan masih 
memberikan harapan dan peluang bagi perempuan, dibanding tidak menggunakan kesempatan itu sama sekali. Lewat pekerjaan di luar rumah yang digelutinya bersama laki-laki, perempuan mempunyai kesempatan untuk mendapatkan kembali transendensinya. Secara perlahan perempuan akan memunculkan dan menegaskan posisinya sebagai subjek. Maka eksistensi perempuan sebagai seorang yang merdeka dan berperan aktif menentukan haluan hidupnya.

\section{Intelektual}

Seorang intelek merupakan anggota kelompok yang nantinya akan berperan krusial dalam usahanya mengusahakan dan membangun perubahan untuk perempuan. Lewat gerakan intelektual dimana didalamnya setiap orang berfikir, melihat, mendengar dan mendefinisikan dirinya.

3. Bekerja untuk meraih transformasi sosial di masyrakat

Senada dengan Satre, Beauvoir mempunyai mimpi dan harapan besar untuk menyudahi koflik antara subjek dengan objek atau Sang Diri denngan Sang Liyan. Antara laki-laki dan perempuan pada khusunya dan antara umat manusia pada umumnya.

Satre menerangkan bahwa seluruh usaha dan perjuangan yang dilakukan manusia pada akhirnya akan ditakdirkan terbelenggu masokisme dan sadisme. Perselisihan dan pertentangan yang terjadi antara satu individu dan invidu yang lain dalam Being and Nothingness, timbul karena motif kebutuhan psikologis yang hadir karena karakter kesadaran itu sendiri. Pada Critique of Dialectical Reason Satre menerangkan bahwa kepetingan ekonomi menjadi alasan utama perselishan dan pertentangan antara pekerja dan kaum sosialis bukan motif kebutuhan psikologi. Implikasinya adalah motif psikologi yang menjadi hambatan selama ini boleh jadi bisa teratasi jika manusia berkecekupan dalam sandang, pangan dan papan.

Sejalan dengan Satre Beauvoir mengamini jika salah satu resep dalam memerdekakan perempuan adalah kuat secara ekonomi. Beauvoir memperingatkan jika sudah barang tentu apabila lingkungan akan menjadi batu sandungan perempuan dalam usaha mendefinisikan diri. Layaknya seorang pelukis yang dibatasi oleh luasnya kertas kanvas yang tersedia, begitupun perempuan yang terbatasi dengan nominal uang yang dia miliki. Keinginan yang di idam-idamkan oleh perempuan dapat mewujud apabila penciptaan lingkungan, dimana masyarakat menyiapkan sokongan yang bersifat materil untuk mentransendensi batasan yang mengkerdilkan posisinya saat ini.

\section{Menolak ke-Liyanan.}

Batasan yang membelenggunya dapat ditampik dengan penolakan atas ke-Liyanan yang selama ini menghinggapinya. Menerima peran sebagai Liyan berarti setuju jika dirinya di objekkan (Beauvoir, 2003). Pembebasan diri perempuan dari tubuhnya mutlak harus dilakukan jika perempuan ingin menjadi Diri yang ada pada masyarakat kita saat ini. Standarisasi kecantikan pada perempuan membuat perempuan terlalu terfokus pada ukuran-ukuran kecantikan dan membandingkanya dengan tubuh miliknya. Beauvoir menuturkan jika kostum dan style acapkali di manfaatkan dalam memangkas tubuh feminin dan gerakanya, lalu menyekatnya dari 
kemungkinan untuk transendensi. Maka perempuan saat ini harus berorientasi pada hal-hal yang memajukan pemikiranya, menggunakan waktunya sebaik-bauknya dalam kegiatan yang kreatif dan inovatif.

Dibawah ini adalah bentuk Eksistensi Perempuan Mesir dalam Novel Perempuan di Titik Nol Karya Nawal El-Saadawi

1. Bekerja

$$
\text { واقترب مني وعرفني، ودهش، فأنا من أحسن موظفات الشركة، وأحسن موظفات الشركة ينصرفن }
$$

Ketika ia lebih mendekat ia mengenali saya, dan tampaknya terkejut melihat saya sedang duduk di situ seorang diri, karena saya dianggap sebagai salah seorang karyawati yang terbaik, dan karyawan-karyawan yang terbaik diharapkan untuk segera pulang seusai hari kerja. (Nawal : 55)

Pada kutipan diatas memperlihatkan Firdaus adalah tokoh yang bersungguh-sungguh dalam bekerja. Hal ini dibuktikan dengan dirinya yang menjadi seorang karyawati terbaik.

Perempuan harus berani bekerja di ranah publik. Mantan Menteri Kelautan Repiblik Indonesia Ibu Susi Pujiastuti, pernah membut pernyataan yang isinya begitu femnisme eksistensial. Beliau berkata "menjadi seorang perempuan bukan berarti kita harus mengorbankan waktu serta usaha untuk menjadi cantik, maka pengorbananya akan berujung rasa semakin tidak percaya diri (Ni Putu Laksmi Mutiara Prameswari, Wahyu Budi Nugroho, \& Ni Made Anggita Sastri Mahadewi, 2019).

Firdaus memberikan contoh bahwa perempuan harus mengaktualisasikan dirinya dan berjenis kelamin perempuan bukanlah sebuah masalah. Perempuan harus menggapai ruang-raung publik dengan bekerja dan berkarya.

2. Intelektual

$$
\begin{aligned}
& \text { أحببت القراءة، وفي كل كتاب كنت أعرف أشياء جديدة: عرفت الفراعنة، وعرفت الفرس والأتراك } \\
& \text { والعرب، قرأت عن جرائم الملوك والحكام، وعن الحروب وثورات الشعوب وحياة الثوار، وقرأت روايات } \\
& \text { الحب وقصائد الغزل، لكني كنت أفضِّل أن أقرأ عن الحكام أكثر محا أقرأ عن الحب،، قرأت عن الحب، }
\end{aligned}
$$

Saya mulai mencintai buku, karena setiap buku memberikan pelajaran baru bagi saya. saya dapat mengetahui tentang orang Parsi, orang Turki dan orang Arab. Saya membaca tentang kejahatan-kejahatan yang dilakukan para raja dan penguasa, tentang perang, tentang rakyat, revolusi, dan tentang riwayat orang-orang revolusioner. saya membaca kisah-kisah percintaan dan sajak sajak cinta. (Nawal : 26-27)

Kutipan diatas mencerminkan tokoh Firdaus sebagai perempuan Mesir yang mencintai halhal yang bernunasa keilmuan. Ketika dia bersekolah di Kairo, Firdaus amat gemar membaca. Pembacaan Firdaus tidak hanya berkisar pada satu tema buku saja, melainkan berbagi bidang keilmuan di baca olehnya. Hal ini mencerminkan firdaus sebagai pribadi yang tidak memilih satu 
bidang keilmuan saja untuk dipelajari, semua ilmu yang kiranya dapat bermanfaat oleh firdaus dipelajarinya.

Firdaus yang masih belajar menyadari akan pentingnya ilmu pengetahuan, yang akan menunjang kehidupanya kelak. Waktunya selama bersekolah di Kairo tidak di sia-siakan untuk halhal yang tidak berguna. Seringkali peluang yang telah diberikan kepada perempuan mengenai pendidikan di sia-siakan, dengan ketidak sungguhan dalam belajar dan banyak fenomena lain. Selain itu pembacaan wanita tentang realitas yang ada dalam lingkunganya mempunyai peran krusial untuk menunjang geraknya ke depan dalam, mengahadapi berbagai masalah yang ada.

Pendidikan memberikan kesempatan kepada perempuan untuk terbebas dari keliyananya. Terlepas adanya pandangan, setinggi apapun pendidikan perempuan dia kembali akan mengurus urusan domestik. Peran seorang ibu yang berpendidikan akan menunjang tumbuh kembang anaknya lebih baik daripada mereka yang tidak berpendidikan. Peran seorang istri yang berpendidikan akan dapat membantu suaminya untuk (memecahkan permasalahan) (problem solving), yang kaitanya dengan keluarga ataupun pekerjaan. Pendidikan adalah kunci perubahan yang diperlukan oleh perempuan.

3. Bekerja untuk meraih transformasi sosial di masyarakat

$$
\text { وتكونت في الشركة ألجنة ثورية برئاسته، وانضممت بغير ألى اللجنة أعمل ليل هار، وفي أيام الإجازات }
$$

Sebuah komite revolusioner telah dibentuk di perusahaan, dengan ibrahim sebagai ketua. Saya bergabung dengan komite tersebut siang dan malam, termasuk pada hari-hari libur. Pekerjaan ini sukarela. Saya tidak lagi menghiraukan gaji saya. (Nawal : 57)

Firdaus sebagai perempuan yang terjun untuk memperjuangkan sebuah transfromasi sosial di masyarakat tampak dengan keikutsertaanya dalam sebuah komite revolusioner. Keikutsertaan Firdaus dalam komite tersebut tidak hanya sebagai formalitas belaka, terbukti dengan dirinya yang intens dalam memperjuangkan komite tersebut. Bahkan dirinya rela tidak di gaji, keikutsertaanya berdasarkan hati nuraninya.

Tatkala perempuan mulai berani untuk unjuk gigi di ruang publik karena merasa dirinya layak, ada saja batu sandungan yang muncul mulai dari ketakutan dari dalam dirinya serta berbagai macam persoalan. Muara dari itu semua adalah perempuan kehilangan kekuatan untuk mempertahankan eksistensinya.

Firdaus adalah gambaran perempuan yang menunjukan eksistensinya di ruang publik, keberadaanya tidak hanya sekedar ada saja, tapi dia juga berani berperan di ranah publik. Firdaus adalah perempuan yang idealis, dia mempertaruhkan tenaganya, waktu dan fikiran untuk kemajuan komite revolusioner. Bagi Firdaus uang bukanlah segalanya maka dari itu uang tidak pernah dihiraukan yang ada adalah kerja sepenuh hati. 
4. Menolak Keliyanan

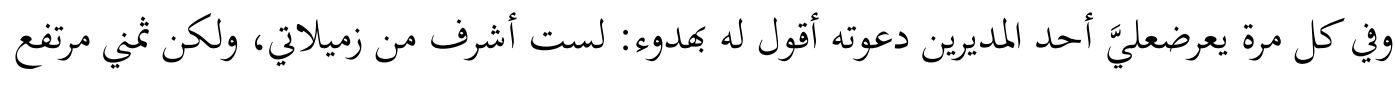

Setiap kali salah seorang direktur mengajak saya berbuat cabul, saya akan mengatakan kepadanya: "Bukan karena saya lebih menghargai kehormatan dan reputasi saya dari gadisgadis yang lainnya, tetapi harga saya jauh lebih tinggi dari mereka." (Nawal : 55)

Firdaus yang bekerja menjadi karyawati swasta di salah satu perusahaan besar, mendapat ajakan tidak senonoh dari direktur perusahaan tersebut. Banyak karyawati yang luluh oleh ajakan direktur perusahaan, berbeda dengan mereka Firdaus menolaknya. Firdaus menyatakan kepada direktur perusahaan tersebut bahwa bukan karena masalah kehormatan dan reputasi yang membuat firdaus menolaknya, melainkan harga Firdaus jauh lebih tinggi daripada harga karywati lain.

Pelecehan seksual yang dialami perempuan tidak jarang terjadi dilingkungan kerja. Pelecehan ini bukan hanya dalam bentuk verbal melainkan dalam bentuk fisik juga. Ada yang menerima karena takut akan dampak yang terjadi apabila melawan. Adapula yang berani melawan dan memilih untuk keluar dari pekerjaanya (Ni Putu Laksmi Mutiara Prameswari et al., 2019).

Firdaus sebagai tokoh utama dalam novel ini, tidak tinggal diam atas pelecehan yang terjadi padanya. Penentangan yang dilakukan Firdaus adalah salah satu bentuk perlawanan yang dilancarkan perempuan di ranah publik. Perlawanan berarti melepaskan tirani yang selama ini menggelayuti mereka.

\section{Kesimpulan}

Firdaus sebagai tokoh utama dalam novel ini telah mengalami manifestasi ketidakadilan gender pada dirinya. Kejadian demi kejadian itu telah dialami oleh dirinya sejak kecil hingga pada titik akhirnya dia dijatuhi hukuman mati. Karena tidak ingin terus menerus tertindas dan tersakiti Firdaus memilih melawan dan memperjuangkan harga dirnya sebagai seorang perempuan. Perjuangan yang dilakukan oleh Firdaus membuat eksistensinya sebagai seorang perempuan muncul. Firdaus adalah penjelmaan perempuan dari teori feminisme eksistensialis dalam sebuah karya sastra. Firdaus berhasil terlepas dari dominasi laki-laki dan memaksa laki-laki untuk mengakui dominasinya. Firdaus berhasil mengaktualisasikan dirinya di tengah kepungan budaya patrarki yang ada di Negara Mesir. Firdaus menasbihkan dirinya sebagai wanita yang hadir ditengah realitas yang berkembang di Mesir, kehadiran Firdaus bukanalah sekedar entitas yang kosong dan tidak bermakna. Firdaus adalah entitas yang lengkap baik secara eksistensi dan esensi.

\section{Referensi}

Batu, P. N. F. L. (2007). Eksistensi Tokoh Perempuan dalam The Other Side Of Midnight Karya Sidney Sheldon. Universitas Diponegoro, Semarang.

Beauvoir, S. de. (2003). Second Sex : Kehidupan Perempuan. Saint Joseph's University.

Beta, P. (2018). Ketidakadilan Gender pada Novel Perempuan di Titik Nol, Karya Nawal El-Saadawi 
Berdasarkan Respon Siswa Kelas Xi SMA Negeri 2 Bua Ponrang. Jurnal Onoma: Pendidikan, Bahasa, Dan Sastra, 3(2). https://doi.org/10.30605/ONOMA.2017.915

Fakih, M. (1996). Analisis Gender dan Transformasi Sosial. Yogyakarta: Pustaka Pelajar.

Haningsih, S. (2005). Pemikiran Riffat Hasan Tentang Feminisme dan Implikasinya terhadap Transformasi Sosial Islam. Al-Mawarid: Jurnal Hukum Islam. Retrieved from https://www.neliti.com/id/publications/26031/pemikiran-riffat-hasan-tentang-feminismedan-implikasinya-terhadap-transformasi

Heraty, T. (2018). Transendensi Feminin: Kesetaraan Gender Menurut Simone De Beauvoir,: Perempuan dalam Aktualisasi Diri sebagai Manusia Bebas. Jakarta: Kompas Gramedia.

Luise von Flotow. (2011). Terjemahan dan Gender: Menterjemah dalam 'Era Feminisme.' In Institut Terjemah Negara Malaysia. Kuala Lumpur: Institut Terjemehan Negera Malaysia dan Pusat Penerbit Universiti (UPENA).

Mansour Fakih. (2008). Analisis Gender \& Transformasi Sosial (2nd ed.). Retrieved from https://inlis.kemenpppa.go.id/opac/detail-opac?id=1709

Ni Putu Laksmi Mutiara Prameswari, Wahyu Budi Nugroho, \& Ni Made Anggita Sastri Mahadewi. (2019). Feminisme Eksistensial Simone De Beauvoir: Perjuangan Perempuan di Ranah Domestik. Jurnal Ilmiah Sosiologi (SOROT), 1(2). https://ojs.unud.ac.id/index.php/sorot/article/view/51955

Pranowo, Y. (2016). Transendensi dalam Pemikiran Simone de Beauvoir dan Emmanuel Levinas. MELINTAS, 32(1), 73. https://doi.org/10.26593/mel.v32i1.1926.73-93

Rosemarie Putnam Tong. (2004). Feminist Thought: Pengantar Paling Komprehensif kepada Aliran Utama Pemikiran Feminis. Retrieved from www.jalasutra.com

Sartre, \& Jean-Paul. (2002). Eksistensialisme dan Humanisme. Yogyakarta: Pustaka Pelajar.

Sholihah, F. (2018). Eksistensi Dā'iyah di Tengah Domestikasi Citra Diri Perempuan Shalihah: Perspektif Feminis Eksistensialis. Sawwa: Jurnal Studi Gender, 13(1), 107. https://doi.org/10.21580/sa.v13i1.2799

Simone de Beauvoir. (2003). Second Sex, Fakta dan Mitos. Surabaya: Pustaka Promethea.

Sugihastuti, \& Saptiawan, I. H. (2010). Gender \& inferioritas perempuan: praktik kritik sastra feminis. Yogyakarta: Pustaka Pelajar.

Suwastini, N. K. A. (2013). Perkembangan Feminisme Barat dari Abad Kedelapan Belas Hingga Postfeminisme: Sebuah Tinjauan Teoretis. Jurnal Ilmu Sosial Dan Humaniora, 2(1), 2303-2898. https://doi.org/10.23887/jish-undiksha.v2i1.1408

Syahrul. (2017). Dilema Feminis sebagai Reaksi Maskulin dalam Tradisi Pernikahan Bugis Makassar. Jurnal Al-Maiyyah, 10(2). 